European journal of American studies

\title{
African-American Music in the Service of White Nationalists: Polish "Patriotic Rap" as a Pop Cultural Tool to Promote National Values
}

Piotr Majewski

\section{OpenEdition}

\section{Journals}

Electronic version

URL: https://journals.openedition.org/ejas/13655

DOI: $10.4000 /$ ejas. 13655

ISSN: 1991-9336

Publisher

European Association for American Studies

Electronic reference

Piotr Majewski, "African-American Music in the Service of White Nationalists: Polish "Patriotic Rap" as a Pop Cultural Tool to Promote National Values", European journal of American studies [Online], 13-3 | 2018, Online since 23 January 2019, connection on 08 July 2021. URL: http:// journals.openedition.org/ejas/13655; DOI: https://doi.org/10.4000/ejas.13655

This text was automatically generated on 8 July 2021

Creative Commons License 


\title{
African-American Music in the Service of White Nationalists: Polish "Patriotic Rap" as a Pop Cultural Tool to Promote National Values
}

\author{
Piotr Majewski
}

\section{Introduction}

Rap music has its roots in jazz, blues, funk and soul which, like rap, have played an important role in the African-American community by reflecting its identity and political endeavors (Keyes; Krims), and helping create the so-called Black public sphere. The New York ghettos of the late 1970s, which produced the "Last Poets" group of poets and musicians, are thought to be the places where rap was born. As argued by the researchers of this music genre, it is the "Last Poets" songs reiterating the slogans spread by other black nationalists and black separatists (Stuckey), the Black Power movement (Wend), the Nation of Islam ideology (Allen) and Malcolm X (Gallen), as well as the Black Panthers (Bloom and Martin) that inspired the rise of rap (Sullivan 205; Kowalewski 21-22).

At its beginning, rap was less conspicuous than other forms of hip-hop culture such as graffiti, break-dance or DJ-ing. This situation started to change following the big success of The Sugar Hill Gang with their 1979 album called Rapper's Delight. It was then that rap came to attract the attention of the media and record companies, previously showing little interest in popularizing this genre. At the same time rap's quick commercial success led to first attempts to censor some of the hip-hop work. The main concern of the music industry was that rappers like Grandmaster Flash and the Furious Five in "The Message" (1982) addressed the sensitive issues of racial and economic segregation and social and political inequality, challenging the ways in which African Americans were being portrayed in American culture (Watkins; Kubrin and Nielson 
187). What added to the confusion was that rap was gaining ground not only among the black ghetto dwellers but also other racial and ethnic minorities and, unexpectedly, white youths. (Kitwana; Wynter). ${ }^{1}$ In response to this phenomenon, there came the first attempts to penalize rap-using both legal and cultural instruments-during the socalled "conservative revolution" proclaimed by President Ronald Regan whose goals were geared towards the social and economic marginalization of minorities, including African Americans. In the late 1980s and early 1990s, special police units were established to observe rappers, interrupt their concerts, and invent evidence to prove that the artists and their fans had broken the law. Efforts were made to influence record companies and broadcasters to censor the rappers' songs or make them refrain from publishing or selling the already produced albums.

At the same time, the predominantly white cultural establishment started to criticize rap lyrics, portraying them as an "attack on American values." The guardians of cultural orthodoxy came out in defense of their class hegemony and cultural supremacy, attempting to squeeze rap into a "wild zone," understood as

a language area repressed from the consciousness of the dominant white culture, pushed outside the boundaries of acceptable verbal expression, as well as outside the limits of acceptable experience. The notion of the linguistic 'wild zone'... shows how the experience of a marginalized group of people... including their individual experiences and expressed in their 'dialect,' was denied access to the disourse shaping the language of their culture.... Instead of throwing itself open to diverse experiences, as pluralist cultures by definition do, American culture seems to impose rules of expression on the experience of minority groups through a pseudouniversal dominant language (which, in fact, is a dialect of white, heterosexual men holding power). As a result, the experience which is incompatible with the rules of the 'dominant language' must be deemed trivial, irrelevant, negligible, narrow, morbid, abnormal, etc. (Kamionowski 35-36) ${ }^{2}$

\section{1. “Political Rap" and African-American Identity Discourses}

Already in the 1980s rappers came to use their music as a weapon to fight the official narratives which composed a stereotypical image of the African-American community. Adopting pseudonyms like "Wise Intelligent," "Professor X" or "Professor Griff" and using a stylized, almost religious rhetoric, many of them built their image of spiritual leaders and teachers of the African-American community. Reconstructing anti-colonial narratives and adjusting them to their contemporary social and economic conditions, those "organic intellectuals" (Hall 267) infused them with elements of other ideologies, like black nationalism and separatism, the Black Power movement, "Black Islam," 3 socialism or Afrocentrism (Collins 76-122). Thus, the conscious rap or political rap, a subgenre of rap music, came into being. It "purposefully refers to the historical models of political protest and is connected with the progressive forces of social criticism" (Dyson 64). It turned out that this kind of musical creativity, being an effective tool of social mobilization, is also increasingly popular among African Americans as a source of knowledge about their own history, challenging the cultural, political and economic status quo. "Political rap" being a product of ghettoization, segregation and racism, is understandable and attractive for its target audience, providing a way to manifest and communicate their "local knowledge," both inside and outside the ghettos, and has become an important element of the black public space (Rose 124; Pough). The music of 
a generation represented by no formal political movement, "conscious rap" became the most popular form of musical expression among young African Americans, as well as a platform for presenting their ideas.

Thanks to the hip-hop culture African Americans, for the first time on such a scale, managed to subvert the oppressive forms of their cultural representation generated by the white majority. In the late 1980s and early 1990s, rap managed to climb out of a cultural niche in the U.S. to become as popular as rock music. As a result, rap came to be a relevant and popular carrier of emancipatory ideas and an element of AfricanAmerican "resistance identity"4 (Lusane 41), one of its goals being to restore and defalsify the African-American memory and to create a counter-memory challenging the widely shared beliefs about white America's past:

Singing about the past struggles-sparked off by the Nation of Islam and Black Panthers-to encourage Blacks to organize themselves, they [rappers] make their music an alternative means of education for the youth who do not have access to the knowledge about the history of black people in America.... From propagating refusal to perform military service to spreading the awareness of how drug addiction or alcoholism harm black communities; from explaining the need of using force in self-defense against racist attacks and police brutality to teaching about Black resistance against the supremacy of whites in the history of Africa and America. (Kowalewski 24)

Stressing the positive influence of rap on the process of reconstruction of the AfricanAmerican identity, one should also point out that the most important issues addressed in the discourse of "conscious" rap, i.e. exclusion, humiliation, racism, violence, poverty, lawlessness, racial pride, black culture and revolution, have been utilized by some rappers to (re)establish the meaning and importance of the basic mythological narratives, creating the ideological core of black nationalism with its extremely chauvinistic dimension. The first of them is the myth of genetic and moral superiority of the black race. Another is the story of an "innocent" civilization once destroyed by the European aggressors, which now has the chance to reinstate itself within the African-American public space. The third one is the myth of a relentless struggle with the age-old enemy, the said white barbarians. Within these narratives, the "black identity" and contemporary racial conflicts are presented in an essentialist perspective, bordering close with racist ideology. According to this essentialist philosophy races have their own unique sets of attributes which are fundamental to their identities. This unique essence is shared by all representatives of a given race and expresses the experience of a homogenous community. "Black essentialism" based on binary oppositions naturalizes and de-historicizes the difference between races and leads to a conclusion that all ideas and activities referred to as "black" are, supposedly out of their nature, progressive and freedom seeking (Jaskułowski 74-76). This essentialist narrative is undermined by, among others, the fact that black masculine culture tends to be oppressive towards women (Collins 161-196) and that the nonAnglo-Saxon people referred to as "ethnics," are also a part of the American society (Novak 330-342). ${ }^{5}$

\section{Hip-hop Culture and Globalization}

In the late 1980s and early 1990s, hip-hop culture gained popularity also outside the U.S. Rap turned out to be a perfect example illustrating the realities of the glocalization 
processes, or the adaptation of global cultural patterns to meet the needs and conditions of local communities. As a result of its popularization, it became internalized and "localized" by other cultures. Enriching it with their own identity narratives, expressed in vernacular languages and musical traditions, they adopted rap as their own "authentic" music. It seems that rap owes its global success not only to the big media companies but also to the power of is message, expressing frustration caused by discrimination, poverty, and lack of empowerment. It is also worth noting that rap has become-in a way unconsciously-a popular ally of many ideas championed by the representatives of the critical postcolonial theory (Spivak). A common denominator of those theories is the intention to undermine the hegemonic worldview used by various colonists to "perceive," "understand," "describe" and "assess" the world and its inhabitants. This is because both rap and the postcolonial theory create a new discursive space where it is possible to empower the "common" people who are politically, socially, economically or linguistically marginalized. By affirming their cultural practices and values, they enable them to present their own ways of thinking and their behaviors. Due to rap, the space provided by popular culture can be filled with alternative orders of knowledge and ideas which challenge the previous structures of power and the narratives they produce (Mitchell).

\section{Rap in Poland: A Historical Outline}

Polish rap has been present in Polish media roughly since 1993, although initially it remained outside the mainstream of Polish culture. Two years later it appeared on such commercial channels as Atomic TV, MTV Poland or VIVA Poland, and the Polish rappers quickly increased their popular appeal (the first Polish rap album was produced in 1995 by a Kielce group called Wzgórze Ya-pa3). ${ }^{6}$ At that point international recording studios including Pomaton, BMG and Sony started to issue and promote albums of Polish rappers (Kleyff 17). ${ }^{7}$ Encouraged by the commercial success of the "street" rap which prevailed in Poland at that time, they jointly embarked on creating its more "cultured" version called "hip-hopolo," a mix of hip-hop and pop aesthetics (Pawlak 52).

In 2006, partly due to the dynamic development of the Internet, Poland's hip-hop stage underwent dramatic changes. In the wake of poor returns big record labels ceased to publish rap albums and the media lost their interest in this genre. In response to this situation, rappers and their fans moved to the Internet, in particular to MySpace, Facebook, YouTube, and later Spotify. To gain independence from the record companies, some of the artists entered the world of business, setting up their own recording studios and launching apparel brands, which helped them finance their artistic activity (Miszczyński 8-9). Although after 2009 some Polish rap videos registered millions of page views, the actual breakthrough for the hip-hop culture came in 2012 with the premiere of Jesteś Bogiem (You're God), a feature movie by Leszek Dawid. This story of the cult rap group Paktofonika reached an audience of 1.4 million and revived interest in rap among the mainstream media.

Today's rap is not only popular with a number of different audiences, but it is also an aesthetically diverse music genre, whose connection with its American origins is not as strong as in the 1990s (Kukołowicz 129). One may find there representatives of street rap, underground, new school (largely commercial), "intelligent" rap, experimental, 
poetic and "patriotic" rap. Moreover, the rappers perform not only in Polish but also in local vernaculars, like the Lemko, Kashubian and Silesian languages. Consequently, today "it is difficult to speak about one hip-hop culture. One should rather highlight the fact of its diversity, seeing this phenomenon as a multitude of voices and performances" (Struzik 166).

\section{Inspirations vs. Originality in Polish Rap: Has Poland Ever Had a "Political Rap"?}

Most of the first Polish rappers, many of whom still perform and enjoy their popularity, were born in 1976-1982. Together with their audience, they were the first generation which grew up in the democratic and capitalist Poland, with full access to the global stream of popular culture. Despite the fact that the Polish and American backgrounds of the hip-hop culture are dramatically different-the Polish rappers and their fans have never been subject to systemic persecution, discrimination or racial segregationthere are still some similarities to be observed. Most importantly, the first Polish rappers, inspired by the lyrics of American rap stars, started to create multilayered stories about the consequences of the Polish transition from the centrally planned socialist economy to free market capitalism. They were rapping about extreme social inequalities, poverty, pathologies, violence, corruption, brutality of the law enforcement officers and about second-class citizens whose lives-regardless of their attitudes or aspirations-became unbearable and purposeless. Those narratives were authored not only by rappers from families whose social and economic status was diminished after 1989, but also by those whose parents benefited from the new economic order and political changes. Apart from their narrative layer, those compositions were greatly influenced by the aesthetics, rituals, performances and musical patterns to be found in different subgenres of the American rap (Kleyff 10-12). The African-American hip-hop culture gave the Polish youths a set of tools and artifacts which came to be processed by them in a wide variety of contexts, and started to function beyond their original historical or cultural context. Using the AfricanAmerican cultural material and infusing it with a new meaning, the people who created the Polish version of American rap sang about their own ideas, experiences and local socio-cultural context. This might actually be the reason why-despite the presence of the aforementioned content, rituals and symbols-the Polish rap cannot be seen as a political music or why one cannot find on the Polish rap stage a direct equivalent of the conscious (political) rap. A great majority of researchers studying the Polish rap maintain that this situation resulted from the fact that

Poland lacked the kind of political or racial conflicts which were present in the U.S., therefore their rap's political energy was not so big.... Yet the Polish hip-hop culture was a form of resistance, admittedly not a radical one, to the dominant culture and to its own subordination.... [However], the Polish rappers have not proposed a positive program of building a new society, and they have not been openly involved in political disputes. (Kukołowicz 122) 


\section{Attitudes Towards Polish Rap and the "Power of Judging"}

The hip-hop culture and the accompanying cultural practices have been seen by a part of our intellectual, scientific and political elites as an "anti-culture," and have become excluded from any "serious" critical or scientific discourse (Pawlak 6-7; Miszczyński 12-13). On the one hand, rappers are still being accused-though not so much as in the 1990s-of promoting negative, if not pathological, behaviors and social relationship models (within this discourse, the hip-hop culture was compared with the subculture of the so-called blokersi, i.e. hooligans living in highrise apartment projects constructed in the socialist period). On the other hand, it is sometimes argued that rap is an artificially transplanted music genre which has little to do with the local musical tradition. Last but not least, rap is still often seen as a "low" or "vulgar" genre, a kind of anti-music, presented in opposition to the "authentic" and "artistic" genres and their aesthetics.

These socially structured labels not only stigmatize rap, rappers and their fans, but they also stand for "the power of judging" and reflect the class-conditioned habitus of the Polish intelligentsia, as well as the arbitrary aesthetic taste of a few generations who were not allowed to openly manifest their views before 1989. The new social and political reality led to the emergence of experts and arbiters of taste, acknowledging their hegemony in the process of ascribing meanings to cultural symbols and diverse types of human activity (Bourdieu 27). The same milieux (academic, political, mediarelated, intellectual) which in the 1970s and 1980s regarded Polish counterculture and music as positive and creative ways of demonstrating defiance against the socialist reality, in the post-1989 period built a new aesthetic hierarchy, with hip-hop at its very bottom. This new cultural system can be described as a cultural apartheid, "where particular aesthetic choices effectively separate social classes, framing them in a stereotypical way.... Within this dominant ideology the popular taste was ignored as naive and self-satisfied, vulgar, nice and easy, in fact, partly animalistic" (Skrzyczkowski 32).

It took time for the Polish nationalists and racists to accept the rap aesthetics, since it was long perceived as alien to their national and civilizational values. Rap was being described as a disruptive musical genre, which could adversely affect the family and the "white" musical aesthetics believed to be an "authentic and direct extension, and a symbol of preserving the racial and civilizational 'essence"' (Pankowski 122):

'The nationalist scene is still mentally stuck in the subculture of the 1990s,' argues Bujak, a rapper who describes himself as a supremacist and a nationalist, who uses rap to communicate his self-identity. Music is a channel of communicating ideas and values. Some people cannot understand how the Left in 1968 managed to wrest the world away from the hands of traditionalists. They all did it in the same way: by tapping into the cultural trends and avoiding ghettoization.... Recently, we've seen many rappers embrace patriotic values, and it really makes me happy.... music is a big thing and if we use it as a tool to spread influence and inspiration, we can win over people's hearts and minds. (Aktyw Północy 2017)

\section{Rap in the Service of the Nation}

Around 2006 Polish rap started to get institutionalized: it began to be used as a tool of a pop-nationalist education to (re)construct the Polish collective memory. One should 
point out that this phenomenon coincided with one of the hottest public debates in Poland after 1989, going on with varying intensity in 2003-2007: it concerned the shape and role of Poland's historical policy (Nijakowski). Rap attracted the interest of national institutions responsible for cultural policy, and in due time those institutions began to sponsor rap songs devoted to a specifically construed vision of the national past. Rappers also became interpreters of the "masterpieces" of national poetic heritage. ${ }^{9}$ It is worth noting, however, that those rappers (including LUC, Sokól, Fisz, O.S.T.R, Peja, Mezo, Bilon and rap bands WWO, Hemp Gru, Zjednoczony Ursynów, all representing a very diverse spectrum of styles) did not typically create or perform songs which could be described as patriotic or political.

It was not until a few years later-when those initiatives had proved successful, both in terms of business and publicity, after they got accepted by the public-that new albums started to appear, this time with the right-wing and nationalistic or historical and martyrological content outweighing other topics. This rap genre, also known as "patriotic rap," started to be promoted by right-wing political parties and their dependent media (since 2015, when Law and Justice, a right-wing party, seized the power, rap became present also in the public media), nationalist organizations, Catholic Church and a growing number of state and local government institutions typically involved in championing nationalistic attitudes. The right-wing, nationalistic politicians and journalists who want to win over the young voters argue that "patriotic rap" is the first musical genre to be described as "truly Polish popular culture." "The elites," as pointed out by Marcin Gawrycki, "usually get to accept the existence of musical genres originating from the disadvantaged social strata once they have gained nationwide popularity; such genres get quickly incorporated into 'the nationalistic discourse"” (11).

The process of the institutionalization of rap, i.e. the embedding of rap in today's nationalization processes, has been facilitated by the fact that in Poland, hip-hop culture has been around for at least twenty years. Rap is not only the music of the young, but it is also listened to by over-thirty and forty-year-olds, which only adds to its acceptance by the public. ${ }^{10}$ The use of fashionable cultural and consumer practices including a special outfit design based on the hip-hop style (and called "patriotic apparel"), not only broadened the audience of the "patriotic rap" but also increased the revenue of those companies which made it a significant component of their marketing strategy. Thus the situation has been reversed, compared to the circumstances of the African-American rap, created as a grassroots, spontaneous element of AfricanAmerican "identity of resistance" which rebelled against the white racism and valorized black nationalism and socialism, as well as the social, political and religious ideas championed by the Nation of Islam.

Meanwhile, the Polish "patriotic rap"-the first strictly political Polish rap style-came into being as a product of an "institutionalized evolution." It became recognized by the state institutions and right-wing organizations and was subsequently utilized as an agent of ideological formation, reinforcing the myths belonging to the nationalist political discourse. The patriotic rap, much as its artists identify themselves as antisystemic rebels, or a minority fighting for their rights, has become an element of a "legitimizing identity" produced by the dominant social institutions to extend and rationalize their domination over other social actors (Castells 22). However, it is by no means a form of a grassroots, subversive cultural practice that empowers the 
disadvantaged social strata, but rather "a translation of a theoretical ideology into a popular idiom" (Pankowski 13). In this perspective, the "patriotic" rappers seem to be pop-cultural "professional vendors of second-hand ideas" (Hayek 11) such as nationalism, libertarianism, white racism, anti-Semitism, Islamophobia and Catholic fundamentalism (Majewski, "Rap jako muzyka tozsamościowa"; Majewski "Polska dla Polaków").

\section{Polish Nationalism and Its Ideological Assumptions}

The ideological core of the "patriotic rap" is grounded in the assumptions that belong to the identity discourse of the Polish nationalist and populist right wing, although some rappers do refer to the U.S.-born ideologies of white supremacy, "new racism," or homegrown neopaganism. The Polish ethnic nationalism was born in the late 19th and early 20th centuries, with Roman Dmowski (1864-1939) deemed to have been the father thereof. For Dmowski the meaning of patriotism was mainly defined in terms of a moral unity of the individual and the nation; the individual had to be unconditionally subjected to the "collective will" of the nation. Dmowski believed that the nation should be based on "physical and moral tyranny" exercised by the "healthy part of the nation" (Dmowski 91). In this way he excluded from the national community all those who he referred to as "a foreign element," i.e. national minorities, liberals, socialists, communists, feminists, or gay people, who were all supposed to be eliminated for the "healthy" part of the nation to be able to survive and perform its historical mission of build a Polish empire in Central and Eastern Europe (Brykczyński).

Dmowski's ideas continue to shape the political imaginary of the right-wing members of the Polish parliament and the extremist nationalist movements. Today, the most influential milieu embracing Dmowski's political and ideological heritage is Law and Justice, the party that has been governing Poland since 2015. Its leader Jarosław Kaczyński, apparently the author of the slogan "Let us repolonize Poland," i.e. make Poland and Poles "truly Polish" again, understands the nation as an organic, biological, cultural, religious and historical community determined by bonds of blood (Balcer 12-13). According to Kaczyński, who previously served as Poland's Prime Minister (2006-2007), national identity should play a key role in the social life of Poles and determine their sense of existence and humanity. At the same time, the terms like civil society, individual freedom or human rights almost never appear in his statements. Kaczyński has consistently built his political position criticizing the democratic state born after the demise of the communist regime, in spite of his personal involvement in the political establishment which came into power in 1989 (he was outside the Parliament only in the period of 1993-1997). Presenting Poland after its transition initiated in 1989 as a country which is a continuation of the communist state and ruled by elites who pursue pro-European and anti-national policies, Kaczyński, along with other right-wing politicians, have idealized earlier forms of the Polish statehood, notably the Commonwealth of Poland and Lithuania and the Second Republic of Poland (Leder). Such "politics of memory" provides the individuals and groups who identify themselves as Polish nationalists with inexhaustible source of nostalgia for past greatness, heroic fight for independence and knightly resistance against foreign domination. 
In keeping with Dmowski's mythic framing of the Polish identity, today's nationalists, including the patriotic rappers, define the Polish nation as: (1) a national community that has been in existence since at least the early Middle Ages, and whose borders are marked by the graves of those who laid their lives in defense of their homeland: "For over one thousand years Jesus Christ has been our king / people are united around him / there is no room left for another religion" (Sekcja WU, "Anty-Jihad"); (2) a guardian of sacred civilizational and spiritual values, with a mission to restore the true faith in the materialistic and cosmopolitan western world: "We're a pack of wolves coming from the East, / Saviors of European Nations, / No force can stop our progress, / Pure blood runs in pure veins.... The voice belongs to the mighty, no more democracy, / The power of age-old supremacy is coming! / No more of your theatricals, of your morbid deviations, / You drug-addicts, you fags, you're all the same / All the people are equal? I will despise them" (Bujak, "The First to Fight"); (3) a community of "true" Poles who are like they were hundreds of years before, although other nations, more numerous, economically and militarily stronger than them, are trying to destroy them, with some help from the traitors: “We, the Poles don't give a shit what the Germans think... It is for us who decide who we want to host at home, / no Eurocommie will ever tell us what to do... The German press is talking about hearltless Poles, let them better remember about the Third Reich... our authorities want to welcome them [the refugees] with open arms. / Who serves whom is obvious enough" (Basti, "Stop"); (4) a nation chosen by God, attached to their past and the Catholic religion, true to traditional morality; resistant to whatever is contrary to human nature: to the mixing of races, religions and languages, as well as "deviations" like homosexualism or gender ideology which the decadent European Union is attempting to implant in Poland: "I guess it's a bad sign, I seem to be too white, / For the modern Europeans to love me, / Worse still, I'm arrogantly proud of being a Pole... I'm not fond of gays, we're not the same, / Those people have always been around, this is the way they are, and let'em be that way, / But no minority will dominate us, / Hands off our weddings, hands off adoption... What father'd like to have a black for a son-in-law?/ Sorry, that's the way it is, / This is not Africa, here winters last half a year, / Such guys will get a Polish girl pregnant only to disappear next, / Tell me, what father would want an Arab for a son-in-law? / What father will bring up his daughter to be a servant? / What father wants his daughter to be a lesbian? / Think of it before you call me a fascist next time!" (Basti, "88 mila"). The nationalistic worldview founded on the above scheme seems to the "patriotic" rappers an unquestionably positive norm.

\section{Tadeusz “Tadek" Polkowski: From Gangstarap to Patriotic Griot}

In the remaining part of this article I would like to focus on the lyrics of Tadeusz "Tadek" Polkowski, one of the most popular "patriotic rap" artists in Poland, to take a closer look at the ideologies at work in this rap sub-genre. Polkowski is sometimes presented as the first to rap about the "cursed soldiers," Captain Witold Pilecki or Inka. Those songs had a great resonance with the football fans groups, but also inspired other rappers to bring up those topics. ${ }^{11}$. In Polkowski's songs and statements made to the media, one could find a majority of topics already addressed by other rappers who 
belong to the "patriotic" rap, notable for its almost automatic repetitive mode of nationalist messages cast into a pop-cultural mould.

Polkowski started his musical career in 2000, co-founding the band called Firma. Their songs usually addressed the topics characteristic of the "street rap." "Tadek" and his friends-who claim the credit for inventing the "JP" abbreviation for "Jebać PolicjĘ" (Fuck the Police), which in turn became the trademark of an apparel brand created by the Firma, otherwise known for its songs about street life, inequality, corruption, poverty, gang violence, prison inmates, binge parties, love for marijuana and hate for the police and the squealers. The Firma's narratives not only commented on the "police state" oppression of "street kids," but also on what the rappers believed were the "true" values. At the same time they allowed the group members to vent their protest against the rules of social life imposed by the elites, which were thoughtlessly accepted by the passive public. As Polkowski explained in a 2013 interview given to a manufacturer of so-called patriotic apparel (owner of the SurgePolonia brand), the values of his subcultural community were not very much unlike those observed by the "true patriots." At the same time, he observed that not all the ideas present in the "street rap" should become a part of patriotic morality:

The street style can have different faces.... it often draws on values: honor, solidarity with friends and family, fidelity, and so on... Today we feel more serious and responsible for our message. It is true that hip-hop promoted things that weren't best for the public. It wasn't didactic, in the best sense of the word, it wasn't only about honor, nobility or passion. That kind of music sometimes had negative influence on the youth, though the intensions were always best. (Nowak)

This narrative, describing the life and worldview of the rappers before their nationalistic "conversion," is quite common among many artists who pursue this style in music. ${ }^{12}$ It is a story about the "sinful" period in their lives, when they fought with "the system," groping for values and a sense of belonging before they experienced conversion, found the right way, and were "born again" in becoming "true Poles," and at the same time another incarnation of the timeless myth of the archetypical hero (Campbell).

Polkowski started his solo career in 2011 and has published two albums to date. The first, Niewygodna prawda (The Uncomfortable Truth), released in 2012 by the RadioWnet was attached to an issue of the Magna Polonia magazine connected with Obóz Narodowo-Radykalny (a far-right organization). The second, titled Niewygodna prawda II. Burza 2014 (Uncomfortable Truth 2. Tempest 2014) appeared in 2014 produced by Fonografika, and was also inserted into an issue of Gazeta Polska, a newspaper subsidized by the Law and Justice party. Since the publishing of his first solo album, "Tadek" has largely given up on his attempts to shape the "communicative memory" of his subcultural community, focusing instead on his efforts to cultivate the "cultural memory" 13 of the entire nation in his capacity as a "carrier of memory": in the view of Assman, cultural memory always needs carriers known under a rich assortment of names, such as "shamans, bards, griots, priests, teachers, artists, clerks, scholars, mandarins, rabbis, and mullahs" (69). In the estimate of a critic friendly to Polkowski,

Polish pop culture hasn't seen such a massive load of patriotic content in a long time... Tadeusz 'Tadek' Polkowski pays homage to the Polish national heroes, educating the young hip-hop audience.... I am convinced that his adolescent, hooded fans, whom the mainstream media describe as hooligans, must feel proud. Son of a distinguished poet Jan Polkowski, Tadek Polkowski gives them a big chunk of Polish history wrapped in the hip-hop 'poetry of the 21st century'... he is ruthless 
both to the traitors to Poland and to the elites of the Third [Polish] Republic, who liked to call on us to 'choose the future.' This album is a warning against the manipulations of mainstream media and blasé celebs. One may say that Niewygodna Prawda is a voice of protest against the entire structure of the Third Polish Republic. For the parents missing a good idea for a present for their children and, at the same time, and who are concerned about their historical education and the prevalence of moral relativism at school, Tadek's album will come like a gift from heavens. (Adamski)

Tadek's involvement with the Firma might seem to be discrediting in the eyes of the predominantly conservative and-at least on the declarative level-nationalistically minded audience. However, the right-wing authors and journalists maintained that the group's songs were an accurate analysis of the post-communist system of oppression, as seen by those who had been socially disempowered by the ruling "arrangement." Polkowski himself stressed that the work of the Firma was a lyrical way to fight the "system" and its central component, i.e. the law enforcement apparatus, infiltrated by the former communist secret service officers (Heron 2017). Having published his first solo album, Polkowski deepened his involvement in "patriotic work," which, as the titles of his successive albums suggested, meant communicating "uncomfortable truths," or events whose memory was either distorted or erased from Polish history. Polkowski's primary objective was to galvanize his audience into critical thinking. After listening to his message, the audience should undergo a "conversion"-similar to the one experienced by the artist-and reject the pathologies, hypocrisy and disfunctionality of the "system":

My mission in this album is to expose those frauds / ... / And this album's message is an uncomfortable truth / uncomfortable for those scoundrels who destroy this country... / This album is about many hidden scars... / about honor and our motherland. / This album is painfully honest, it's be about traitors and real heroes... / It's about memorials which are still missing/ And about the cursed soldiers. (Tadek Firma Solo, The Uncomfortable Truth)

For Polkowski, those who marginalize, ignore, and distort Polish history act in league with the postcommunist and liberal elites who conspire with external enemies to keep Poland a German, Russian or European "colony." It is those two groups that fear the "truths" that Polkowski has set out to unveil. "Once I stumbled upon some sociological research results which said that $93 \%$ of the Polish elite originates from the Polish People's Republic," said Polkowski in one of his interviews and added:

Thus, bluntly speaking, in the 21st century Poland we have post-Soviet elites. The same is true of the media or universities. If the political line of a newspaper or TV station is determined by people-or children of those people-who were actively involved in the Sovietization of Poland and eagerly served the communist propaganda, it won't be an overstatement to say that to a large extent the media pose a threat. (Meller)

To unveil those "uncomfortable truths" is a source of empowerment and will enable the Poles to "decolonize" and "repolonize" their country. An important role in this "unmasking of lies" is to be played by the patriotic rappers, or the popcultural "leaders of memory."

Polkowski and other rappers' songs classified as "patriotic rap" are grounded in ideological essentialism, marked-like in the case of some American rappers who refer to the ideology of black separatism-by binary oppositions which claim to encompass all possible attitudes towards reality. On one side of this Manichean divide we can find "the truth" and "patriots," on the other, "lies" and "the enemies who exploit them." 
The discursive power of this essentialism is based on the naturalization and dehistoricization of those binary oppositions and on the stable and unchanging meanings that are ascribed to them. All selectively picked events and individuals, serving as examples of the "genuine love for the motherland" or, to the contrary, of "treason / enmity," symbolize the sets of values and attitudes characteristic of those two opposites. Within this discourse, a hero, a traitor, or enemy of the nation

is never just an individual, a single life trajectory, or a protagonist of one eventhe/she must always represent a community, or something bigger and more important than themselves, be an embodiment of some paradigm.... The life of a hero... is defined not only by their character but also by their 'belonging,' because their conduct and what happens to them depend on what they belong to and where their place is, rather than on what they are like. (Karahasan 72)

\section{Conclusions}

The rise of "patriotic" rap, a showcase for the internalization of global cultural practices and adapting them to local conditions, demonstrates how such adaptations may serve dramatically different functions than the "original" cultural products. The black political rap used to function in the public sphere of the 1980s and 1990s America as music that became a significant part of African-American identity, built in opposition to the dominant group and challenging the existing power structure along with the its legitimizing discourses. In comparison, the Polish "patriotic" rappers effectively became pop culture promoters of the nationalist ideology which has come to take hold in Poland. Their aim, however, is not a struggle for the empowerment of the oppressed; instead, the patriotic rap is reinforcing a vision of the world which is grounded in a nationalist mentality. The music they create-the first strictly political music genre in Poland-emerged not in opposition to the power structure (which was the case of American rap) but with a generous support of the state and its institutions, public and private media, as well as right-wing and nationalistic circles.

Adamski, Łukasz. "Tadek Niewygodna Prawda-tak powinno uczyć się patriotyzmuRecenzja". wPolityce.pl. 27 Nov. 2012. http://wpolityce.pl/kultura/246777tadekniewygodna-prawda-tak-powinno-uczyc-sie-patriotyzmu-recenzja. Accessed November 30, 2018.

Allen, Ernest Jr. "Religious Heterodoxy and Nationalist Tradition: The Continuing Evolution of the Nation of Islam." The Black Scholar 26.3/4 (1996): 2-34. Print.

Assmann, Jan. Pamięć kulturowa: Pismo, zapamiĘtywanie i polityczna tożsamość w cywilizacjach starożytnych. Trans. Anna Kryczyńska-Pham. Warszawa: Wydawnictwa UW, 2008. Print.

Balcer, Adam. Beneath the Surface of Illiberalism: The Recurring Temptation of 'National Democracy' in Poland and Hungary -With Lessons for Europe. Warsaw: WiseEuropa, 2017. Print.

Bloom, Joshua, and Waldo E. Martin. Black Against Empire: The History and Politics of the Black Panther Party. California: University of California Press, 2014. Print. Bourdieu, Pierre. Dystynkcja: społeczna krytyka władzy sĄdzenia. Trans. Piotr Biłos. Warszawa: Scholar, 2005. Print.

Brykczyński, Paweł. Primed for Violence. Madison: University of Wisconsin Press, 2016. Print. 
Campbell, Jospeh. The Hero with a Thousand Faces (The Collected Works of Joseph Campbell). Novato: New World Library, 2008. Print.

Castells, Manuel. Siła tożsamości. Trans. Sebastian Szymański. Warszawa: Wydawnictwo Naukowe PWN, 2008. Print.

Collins, Patricia. From Black Power to Hip Hop: Racism, Nationalism, and Feminism.

Philadelphia: Temple University Press, 2006. Print.

Dmowski, Roman. Myśli nowoczesnego Polaka. Wrocław: Nortom, 2002. Print.

Dyson, Michael Erick. Know What I Mean? Reflections on Hip Hop. New York: Basic Civitas, 2007. Print

Gallen, David ed. Malcolm X: As They Knew Him. New York: Ballantine Books, 1995. Print. Gawrycki, Marcin Florian. (I)grajĄc ze smakiem: muzyka tożsamość $i$ polityka na Karaibach. Warszawa: Wydawnictwa Uniwersytetu Warszawskiego, 2013. Print. Gramasci, Antonio. Selections from the Prison Notebooks of Antonio Gramsci. Ed. and trans. Quintin Hoare and Geoffrey Nowell Smith. New York: International Publishers, 1971. Print.

Hall, Stuart. "Cultural Studies and Its Theoretical Legacies." Stuart Hall: Critical Dialogues in Cultural Studies. Ed. Morley David and Chen Kuan-Hsing. New York: Routledge, 1996. 262-275. Print.

Hayek, Friedrich August von. Intelektualiści a socjalizm. Warszawa: Prohibita, 1998. Print. Heron, Wojciech. “'Zrozumiałem, że lepiej zło dobrem zwyciężać.’ Wywiad z Tadeuszem “Tadkiem” Polkowskim.” 15 May 2017. Radio Maryja. http://www.radiomaryja.pl/ informacje/zrozumialem-ze-lepiej-zlo-dobrem-zwyciezac-wywiad-tadeuszem-tadkiempolkowskim/. Accessed November 30, 2018.

Hirsch, Lilly. E. "Rap as threat? The Violent Translation of Music in American Law." Law, Culture and the Humanities (2014): 1-19. Print.

Hooks, Bell. "Postmodernistyczna czerń.” Trans. Ewa Łuczak. Kultura, tekst, ideologia. Dyskursy współczesnej amerykanistyki. Ed. Preis-Smith Agata. Kraków: Univeristas, 2004. 429-439. Print.

---. "Postmodern Blackness." http://www.africa.upenn.edu/Articles_Gen/

Postmodern_Blackness_18270.html. Accessed November 30, 2018.

Jaskułowski, Krzysztof. "Kultura popularna jako bole bitwy: wokół kulturoznawstwa krytycznego Stuarta Halla." ŚciĘgna konsumpcyjne. Próby z kulturoznawstwa krytycznego. Ed. Burszta Wojciech Józef and Czubaj Mariusz. Gdańsk: Wydawnictwo Katedra, 2013.

51-77. Print.

Kamionowski, Jerzy. “LeRoi Jones / Amri Baraka - Kaliban w płaszczu Prospera.” Czarno na białym. Afroamerykanie, którzy poruszyli AmerykĘ. Ed. Łuczak Ewa, Antoszek Andrzej. Warszawa: Wydawnictwo Uniwersytetu Warszawskiego, 2009. 29-66. Print.

Karahasan, Dževad. Sarajewska sevdalinka. Trans. Joanna Pomorska and Danuta CirlićStraszyńska. Sejny: Pogranicze, 1995. Print.

Keyes, Cheryl L. Rap Music and Street Consciousness. Urbana: University of Illinois Press, 2002. Print.

Kitwana, Bakari. Why White Kids Love Hip Hop: Wankstas, Wiggers, Wannabes, and the New Reality of Race in America. New York: Civitas Books, 2006. Print.

Kleyff, Tomasz. "Rzut oka wstecz.” WĘcławek Dominika, Flint Marcin, Kleyff Tomasz, Cała Andrzej, Jaczyński Kamil. Antologia Polskiego Rapu. Warszawa: Narodowe Centrum Kultury, 2014. 10-25. Print.

Kowalewski, Zbigniew M. RAP: miĘdzy Malcolmem X a subkulturA gangowĄ. e-Book. 
Krims, Adam. Rap Music and the Poetics of Identity. Cambridge: Cambridge University Press, 2000. Print.

Kubrin, Charis E., and Erik Nielson Erik. "Rap on Trial.” Race and Justice 4.3 (2014): 185211. Print.

Kukołowicz, Tomasz. Raperzy kontra filomaci. Warszawa: Narodowe Centrum Kultury, 2014. Print.

Kurnicki, Karol. “'Dziś w moim mieście’: społeczna i polityczna przestrzeń codzienna w hip-hopie." Hip-hop w Polsce: Od blokowisk do kultury popularnej. Ed. Miszczyński, Miłosz. Warszawa: Wydawnictwa Uniwersytetu Warszawskiego, 2014. 144-164. Print. Leder, Andrzej, Prześniona rewolucja. Ćwiczenia z krytyki historycznej. Warszawa: Krytyka Polityczna, 2014. Print.

Lusane, Clarence. "Rap, Race and Politics” Race \& Class 35.1 (1993): 41-56. Print. Majewski, Piotr. "Rap jako muzyka tożsamościowa: od czarnego getta do polskiego popnacjonalizmu." Sprawy Narodowościowe. Seria nowa 47 (2015): 57-79. Print.

---. "Polska dla Polaków, nie żaden kurwa Achmed-analiza narracji islamofobicznych w polskim rapie." Kultura Popularna 51 (2017): 106-116. Print.

Meller, Adam. "Wywiad z Tadkiem z krakowskiej Firmy nt. patriotyzmu i polskiej historii." 13 July 2012. konserwatyzm.pl. https://www.konserwatyzm.pl/artykul/4822/ wywiad-konserwatyzmpl-z-tadkiem-z-krakowskiej-firmy-nt-patri>. Accessed November 30, 2018.

Mitchell, Tony, ed. Global Noise: Rap and Hip Hop Outside the USA. Middletown: Wesleyan, 2002. Print.

Miyakawa, Felicia. Five Percenter Rap: God Hop's Music, Message, and Black Muslim Mission. Bloomington and Indianapolis: Indiana University Press, 2005 Print.

Miszczyński, Miłosz. “Hip-hop w Polsce. Od blokowisk do kultury popularnej”. Hip-hop $w$ Polsce. Od blokowisk do kultury popularnej. Ed. Miłosz Miszczyński. Warszawa: Wydawnictwa Uniwersytetu Warszawskiego, 2014. 7-18. Print.

Nijakowski, Lech. M. Polska polityka pamiĘci. Esej socjologiczny. Warszawa: WAiP, 2008.

Print.

Novak, Michael. The Rise of the Unmeltable Ethnics: Politics and Culture in the Seventies. New York: Mcmillan, 1973. Print.

Nowak, Krzysztof. “'Tadek: Nawijanie może być muzycznĄ publicystykĄ.' Wywiad.” 12 Dec. 2013. SurgePolonia.Blog. http://blog.surgepolonia.pl/2013/12/tadek-nawijaniemoze-byc-muzyczna-publicystyka-wywiad/. Accessed November 30, 2018.

Nowak, Krzysztof. “Tau: 'Budujmy patriotyzm na miłości.' Wywiad.” 13 Jan. 2014.

SurgePolonia.Blog. http://blog.surgepolonia.pl/2014/01/tau-budujmy-patriotyzm-namilosci-wywiad-2/>. Accessed November 30, 2018.

Pankowski, Rafał. Rasizm a kultura popularna. Warszawa: Trio, 2006. Print. Pough, Gwendolyn D. Check It While I Wreck It: Black Womanhood, Hi-Hop Culture, and the Public Sphere. Boston: Northeastern University Press, 2004. Print.

Rose, Tricia. Black Noise. Hanover: Wesleyan University Press, 1994. Print.

Skrzyczkowski, Konstanty. “Czego słuchasz?-wolność i dyskryminacja w gustach muzycznych.” Kultura i polityka. Sztuka i polityka. Muzyka popularna. Ed. Jeziński Marek, Wojtkowski Łukasz. Toruń: Wydawnictwo Naukowe Uniwersytetu Mikołaja Kopernika, 2012. 29-42. Print.

Spivak, Gayatri. Strategie postkolonialne. Trans. Maciej Kropiwnicki et al. Warszawa: Wydawnictwo Krytyki Politycznej, 2011. Print. 
Stuckey, Sterling. Slave Culture: Nationalist Theory and the Foundations of Black America. New York-Oxford: Oxford University Press 1987. Print.

Sullivan, Denise. Keep on Pushing: Black Power Music from Blues to Hip-Hop. Chicago:

Chicago Review Press, 2011. Print.

Struzik, Justyna. "Seks i kapitalizm. Polski przypadek kultury hip-hopowej." Hip-hop w Polsce. Od blokowisk do kultury popularnej. Ed. Miłosz Miszczyński. Warszawa:

Wydawnictwa Uniwersytetu Warszawskiego, 2014. 165-180. Print.

Watkins, Craig. Hip Hop Matters: Politics, Pop Culture, and the Struggle for the Soul of a

Movement. Boston: Beacon Press, 2006. Print.

Wend, Simon. "The Roots of Black Power. Armed Resistance and the Radicalization of the Civil Rights Movement." In The Black Power Movement. Rethinking the Civil RightsBlack Power Era. Ed. Peniel E. Joseph. New York: Routledge, 2006. 145-166. Print.

Wynter, Leon E. American Skin: Pop Culture, Big Business, and the End of White America. New York: Crown, 2002. Print.

"Wywiad z Bujakiem, przedstawicielem nacjonalistycznej sceny Rap." 19 Oct. 2017. Aktyw Północy. http://www.aktyw14.net/index.php/artykuly/publicystyka/695wywiad-z-bujakiem-przedstawicielem-nacjonalistycznej-sceny-rap. Accessed November 30, 2018.

"Wywiad z chuliganem odcinek 44 - Tadeusz Polkowski." 2 Nov. 2017.

stadionowioprawcy.net. http://stadionowioprawcy.net/news/wywiad-chuliganemodcinek-44-tadeusz-polkowski/. Accessed Nov. 30, 2018.

Zakszewska, Sandra. “Kogo najczĘściej słuchali Polacy w 2017 roku?” 12 Dec.2017. Tuba.pl. http://tuba.pl/tubapl/7,103887,22774669,kogo-najczesciej-sluchali-polacyw-2017-roku.html. Accessed Nov. 30, 2018.

\section{NOTES}

1. Leon Wynter showed how the marginalized African-American culture, symbolized through rap, hip-hop street wear and "gangsta" lifestyle, transformed into a counterculture and was later taken over and commercialized by American corporations. Wyner points out that although rap is being predominantly created by African Americans the proportions change dramatically in the case of the ownership of the record companies, producers and the people in charge of the music industry (Wynter). Other researchers argue that the modern rap actually reinforces stereotypes about Afro-Americans and promotes materialism, violence, sexism and antiintellectualism (Pope; Collins 161-196).

2. Courts in the U.S. increasingly use rap lyrics as decisive evidence in lawsuits against their authors. Chris E. Kubrin and Erik Nielson and Luly Hirsh, who analyzed the way the lawsuits based on circumstantial evidence were conducted (with a few dozen rappers sentenced to longterm imprisonment or capital punishment) argue that the verdicts were based solely on the literal interpretation of the "street" poetry (Kubrin and Nielson; Hirsch).

3. Many rap stars are connected not only with the "Nation of Islam" (NOI) but also with The FivePercent Nation, a syncretic socio-religious movement established in Harlem in 1964 by Clarence 
Edward Smith, a former NOI member and Malcolm X's disciple, who adopted the name of Clarence 13X and became famous as Allah the Father. Allah left the Nation of Islam since he did not accept its doctrine saying that "all white people have been tainted with the original evil" and he rejected the idea that Wallace Fard Muhammad, the first founder of the Nation of Islam, was actually Allah himself. Instead, he went on to preach that the original black man was God and the original black woman was Mother Earth. According to the teachings of the Five Percenters, also known as "The Nation of Gods and Earths," black people were the first people to inhabit the earth and thus they are the fathers ("Gods") and mothers ("Earths") of all people. The Gods and Mother Earths being $5 \%$ of the global population (hence the name of the movement), they perceive themselves as enlightened researchers/scientists, whose aim is to find absolute knowledge and evidence to corroborate it. Their goal is to preach to the unenlightened, i.e. those who worship a false Mysterious God and atheists who compose $85 \%$ of the global population, and to fight with the remaining $10 \%$ of humanity who know the truth about the Mysterious God but use this knowledge to control the previously mentioned $85 \%$ of people. According to the Five Percenters, those people include the higher clergy of the Christian and other religions, authority officials, media people, members of international finance and corporate establishment. The Five Percenters do not constitute a monolithic group of believers who act according to the same consistent religious doctrine, and their spiritual endeavors are based on their individual experience. Moreover, with some of their members being, in fact, white individuals, this movement rejects the ideology of black supremacy. The teachings of Five Percenters became quite popular among African-American intellectuals during the Civil Rights Movement, and in the 1980s and 1990s they were among the most important sources of inspiration for "political" rappers. Among the activists belonging to Five Percenters or those who declared to have sourced inspiration from their religious assumptions and beliefs, one can name the following artists: Gang Starr, Mobb Deep, Poor Righteous Teachers, Jurassic 5, Mos Def, Everlast, Eve, Common, Rakim, Big Daddy Kane, Brand Nubian, Jay Z, Wu-Tang Clan, Gravediggaz, Busta Rhymes, Killah Priest, Nas, Erykah Badu, Queen Latifah, the Guru or Tribe Called Quest (Miyakawa).

4. Manuel Castells points out that “'resistance identity' is generated by those actors who are in positions/conditions devalued and/or stigmatized by the logic of domination, thus building trenches of resistance and survival on the basis of principles different from, or opposed to, those permeating the institutions of society.... Naturally, identities that start as resistance may induce projects, and may also, along the course of history, become dominant in the institutions of society, thus becoming legitimizing identities to rationalize their domination. Indeed, the dynamics of identities along this sequence shows that, from the point of view of social theory, no identity can be an essence, and no identity has, per se, progressive or regressive value outside its historical context" (Castells 8).

5.

Applying a critical perspective to the set of ideas comprising black essentialism, one needs to understand its context. This is explained by bell hooks: "Part of our struggle for radical black subjectivity is the quest to find ways to construct self and identity that are oppositional and liberatory. The unwillingness to critique essentialism on the part of many African-Americans is rooted in the fear that it will cause folks to lose sight of the specific history and experience of African- Americans and the unique sensibilities and culture that arise from that experience. An adequate response to this concern is to critique essentialism while emphasizing the significance of 'the authority of experience.' There is a radical difference between a repudiation of the idea that there is a black 'essence' and recognition of the way black identity has been specifically constituted in the experience of exile and struggle" ("Postmodern Blackness").

6. Parallel to its American model, Polish hip-hop culture was born at youth clubs, commonly present in major Polish cities. By the end of the 1990s, the Polish rap began to diversify-in terms of its lyrics and sound-depending on the region the rappers came from. Their songs would 
feature elements of different slangs, as well as different American rap subgenres the individual Polish rappers were inspired by. The Warsaw rap scene, for example, was inspired by the New York rap sound, while the Poznan rappers mostly took to the California (West Coast) style (Kleyff 14). Among the most popular American rappers in Poland were such artists and bands as: 2PAC, Snoop Dogg, Dr. Dre, Ice Cube, 50 Cent, N.W.A, The Game, The Notorious B.I.G.DMX, Xzibit, Mobb Deep, Eazy-E, Busta Rhymes, Ice-T, Ice Cube, Onyx, Bone Thugs-N-Harmony, D12, Wu-Tang Clan, G-Unit, Cypress Hill, Ol' Dirty Bastard, Nas, Eminem, Lloyd Banks, The Fugees, Outkast, Nate Dogg, Compton's Most Wanted, Jay Z, Fat Joe, Luniz, Young Jeezy, Outlawz, Lil' Wayne, Raekwon, Method Man, Big Punisher, Public Enemy, GZA/Genius, Puff Daddy, House of Pain, Beastie Boys, A Tribe Called Quest, Redman.

7. Tomasz Kukłowicz comments on the 2005 and 2009 opinion polls concerning the social profile of the rap audience in Poland as follows: "At that time, rap was the music of young people. In the group of those up to 24 years of age, its popularity rate reached $40 \%$. Its audience was rather male than female, including individuals with average and just below average incomes, rather than the very poor or the very rich. Rap's popularity decreased along with the rise of the level of education. The genre was equally popular in towns and cities as well as in the country" (151).

8. As early as in 2014 Karol Kurnicki wrote that "Polish hip-hop was not politically polarized; it was never either left or right oriented.... Instead, it is mainly post-proletarian (popular?), i.e. connected with the situation of the urban dwellers whose position is determined by the neoliberal economic transition. Therefore it comes as no surprise that the criticism expressed in Polish hip-hop songs is typical of the societies involved in the capitalist transition. It either assumes a 'social' position (meaning it highlights economic problems), or an 'artistic' one, emphasizing the pursuit of creativity and personal freedom over the socio-bahavioral matters" (161-162).

9. The Warsaw Uprising Museum (WUM) is particularly instrumental in utilizing music to promote its own historical policies. It became the first public institution in Poland hiring rappers to create songs about the Warsaw uprising. In 2007, WWO, a popular Warsaw group together with Kapela Czerniakowska recorded the song titled "Pierwszy sierpnia" (The First of August) commissioned by the WUM and the Institute of National Remembrance in association with the Discovery History TV channel. In 2009, the WUM was involved in co-producing a song by Hemp Gru "63 dni chwały" (63 Days of Glory); this group also created the soundtrack to the movie Sierpniowe niebo. 63 dni chwaly (The August Sky. 63 Days of Glory), produced in association with the WUM in 2013. For over ten years, different rappers have been performing at concerts organized annually by the WUM to commemorate the Uprising.

10. According to Spotify, the most popular streaming platform in Poland, in 2017, hip-hop made 30 out of 50 most popular Polish artists, with Taco Hemingway (over 50m listener streams), Quebonafide, O.S.T.R., Paluch and Białas topping the list. (http://tuba.pl/tubapl/ 7,103887,22774669,kogo-najczesciej-sluchali-polacy-w-2017-roku.html).

11. The term "cursed soldiers" is quite controversial and has been used in the public discourse only since the 1990s. It refers to loose guerrilla squads which following the end of World War II continued to fight with the Soviet secret services and their Polish communist counterparts. Most of those squads were either eliminated or disbanded by the end of 1947. Some of them took to criminal acts like looting, banditry, murders and even genocide on civilians, including national minorities (Belarusians, Lithuanians, Ukrainians and Jews). Witold Pilecki was a member of the Polish underground state, a soldier of the Home Army, and a prisoner of KL Auschwitz where he set up a resistance movement; he was also the author of one of the first reports from Auschwitz (so called Pilecki's Reports). In 1948, he was sentenced to death by the Polish communist authorities. Danuta Helena Siedzikówna alias Inka, was a nurse helping one of the Home Army squads which fought with the Nazis during the Second World War. Next, she served in a guerilla squad which fought after the war with the communist authorities. Arrested in 1946, she refused 
to testify against the members of the armed resistance. Siedzikówna was sentenced to death at the age of 18.

12. A rapper with the stage name of Tau, for example. says that he discovered patriotism thanks to the Holy Spirit: "First of all I experienced a really deep conversion and received a gift-though I don't want to sound vain-the wisdom of the Holy Spirit.... My patriotism is connected with my conversion.... My faith in Jesus Christ led me to all the other values, like for example, patriotism.... For the last two years I have been a bit of a hypocrite but in order to get myself out of some serious trouble, I had to go a long way to understand my faith and patriotism. (http:// blog.surgepolonia.pl/2014/01/tau-budujmy-patriotyzm-na-milosci-wywiad-2/).

13. According to Jan Assman, communicative memory consists of memories referring to a recent past, a case in point being generational memory (66-67). Cultural memory is described by the German scholar as a "foundation memory," oriented toward fixed points in the past which help define the group's identity (67-68).

\section{ABSTRACTS}

In today's world, cultural products, technologies, information and ideologies easily transcend national borders, and the history of the internationalization of rap music is a good example of this phenomenon. Rap has not only become a symbol of the IT revolution and the prevalence of the western capitalist business practices, but also a cultural tool used by some marginalized groups to express their identity. The first part of this article explains how rap, having become an important element of African-American culture, enabled its audience and artists to manifest and communicate their ideas, beliefs and values, including those that are rooted in the culture of black nationalism. In the second part, I provide an outline of the history of Polish rap and trace the African-American influences, to finally focus on the rise of a specific Polish subgenre called "patriotic rap."

\section{INDEX}

Keywords: nationalism, consumerism, popular culture, hip-hop culture, "political rap, " Polish rap, "patriotic rap" "culture war"

\section{AUTHOR}

\section{PIOTR MAJEWSKI}

Piotr Majewski, Ph.D., Assistant Professor in the Faculty of Humanities and Social Sciences of the SWPS University, Warsaw, is an anthropologist and a sociologist. His academic interests includeurban anthropology, anthropology of sport, sociology of popular music and of nationalism. 